\title{
Employee Engagement: A Quantitative Review and Its Relationship with Job Satisfaction and Employee Performance
}

\author{
Achmad Sani Supriyanto ${ }^{1,}$ Vivin Maharani Ekowati ${ }^{2},{ }^{*}$ Zahara Tirta Pujianto ${ }^{3}$, \\ Masyhuri $^{4}$ \\ 1,2,3 UIN Maulana Malik Ibrahim Malang, Indonesia \\ ${ }^{4}$ Islamic University of Malang, Indonesia \\ *Corresponding author.Email: vivien.maharani@yahoo.com
}

\begin{abstract}
Employee engagement becomes priority among businesses as it can trigger a better performance. This research aims to reveal the influence of employee engagement to the employee performance with job satisfaction as an intervening variable. It is a quantitative research with an explanatory approach to explain the causal relationships of the hypotheses used. The research samples are 75 employees of PDAM in Malang city. Data were collected through questionnaires. Data were analyzed using path analysis. This study show that employee engagement has direct effect on employee performance. It effects employee performance through job satisfaction. It concludes that the engagement of the employees of PDAM in Malang is great, so their performance improves.
\end{abstract}

\section{Keywords: Employee Engagement, Employee Performance, Job Satisfaction}

\section{INTRODUCTION}

Some researchers have lately been focusing more on employee engagement. Many of them claim that employee engagement predicts employee behavior and employee performance [1], [2]. On the other time, it has been informed that employee involvement is declining and there has been a deep work termination [3]. The increase of PDAM customers in Malang is not in line with the decrease of the employees every year. The number of customers from 2019 to 2020 increases by $0.49 \%$, while that of the employees decreases by 0.59 percent. There found also a decrease in the attendance statistics from October to December by $10 \%$ and an increase of lateness from November to December 2019 by $54 \%$ or 418 cases from the 327 employees [4]. Unfortunately, most researches about employee engagement come from the literature of practitioners and companies. A research based on academic literature is still lacking [2].

The data raise a question on why the number of employees is decreasing while the number of customers goes on the other way around, and what is the cause of the attendance decrease and the high number of lateness. One of the causes might be the low engagement of employees [3]. Handoyo \& Setiawan reveal that employee attachment effects the progress of the company through performance, productivity, attendance, and retention [5]. It indicates a lack of employee engagement in the company due to relatively high cases of lateness. Siddhanta and Roy [3] and Markos and Sridev [6] note that one of the benefits of employee engagement is the impact on employee attendance.

Scahufeli and Bakker define engagement as a positive thing associated with work characterized by vigor and dedication [7]. Saks suggests that job involvement is the result of a cognitive assessment on an individual's habit to carry out the job, and it is associated with his/her personal image. Job involvement includes of emotional, and ability component correlated with performance's individual [1].

Some studies by [3] and [5] suggest that employee involvement and worker performance can lead to the company success. Lianasari, and Paulus [8], Muliawan et al. [9], Jelagat and Josphat [10] said that employee engagement effects performance and job satisfaction. Other researches by [11]-[19], [2] go to similar results that employee performance is influenced by employee involvement. However, some studies also prove that there is no influence of employee engagement to the employee performance [20][21]. They reveal that there is no increase in the employee performance once employee engagement is increased. Meanwhile, researches by [2], [22]-[24] indicate that 
employee engagement effects on job satisfaction. Shamailan notes that employee satisfaction is directly bounded with employee engagement [25].

Finding the contradiction, this study attempts to provide an explanation of employee engagement and propose a framework on the performance mediated by job satisfaction through empirical study on the previous researches. It aims to integrate the employee involvement, job satisfaction, and employee performance in a model that other researchers can use to understand the employee performance. Under the description, this study is intended to examine the influence of employee engagement on employee performance; examine and analyze the influence of job satisfaction on employee performance; examine and analyze the influence of employee engagement on job satisfaction; and examine job satisfaction as mediation variable.

\section{RESEARCH HYPOTHESIS}

Scahufeli, and Bakker define worker engagement as a dedication, enthusiasm, and full attention of the worker coming from the positive thinking, satisfaction, and other things associated with their work [7]. Employee performance is basically the work result of the employees during certain period [26]. According to Harsuko performance refers to how a person has played his role in applying the organization strategy to achieve either certain goals related to personal role or to show competence relevant for the organization [27].

Nurbaity and Sulistyo suggests that worker engagement has a great correlation on performance because when employees are highly engaged with the entire organization, their performance could obviously increase[28]. Sundaray concluded that an organization with higher level of employee engagement is upper hand than the competitors as it provides competitive advantage to the companies through productivity [29].

H1: Employee Engagement directly effects employee performance.

Aprianto and Yoyok [30], Sani and Maharani [31] state that job satisfaction is an attitude and a statement showing a pleasant or positive emotion towards his/her job experience. Meanwhile, the indicators of job satisfaction by Robbins and Judge regarding the theory of two factors, which are motivation and hygiene factor [32]. Motivation factor is an aspect of work that motivates an employee to perform and satisfy the company. Motivational factors consist of: a) Achievement, b) Recognition, c) the Work Itself, d) Advancement, and e) Growth.

Mangkunegara reveals that Performance is a measure of the quality and quantity of work done by a person based on the responsibilities assigned to him [33]. Employee performance is one of the work attitudes that is essential to support the performance of the organization [34]- [35].

H2: Job satisfaction directly effects employee performance.
Siswanto [36] and Bedarkar and Pandita [37] suggested that employee engagement is made by the positive emotions of the employees including happiness, excitement, and enthusiasm. The affirmative effect are positive words uttered to let a person believe in the potential of the actions made. Markos and Sridevi said that the concept of employee engagement is related to management, such as commitment, behavior of the organizational parties, and job satisfaction [6].

H3: Employee engagement directly effects on job satisfaction.

Siswono argue that employee engagement can be seen in the energy, involvement, and focused effort to achieve the organizational goals [17]. Ghafoor said that once the employees feel as a part of the organization, their identity with the organization will increase [38]. Markos and Sridevi said that the concept of employee engagement is related to management, such as commitment, behavior of the organizational parties, and job satisfaction [6]. According to Handoko, employees who get job satisfaction will work better [39]. Oxy and Heru [40] and Merry and Syarief [13] show job satisfaction has a significant effect. The more satisfied the employees are, the better the work performance and result will be.

\section{$\mathrm{H} 4$ : Job satisfaction is mediation variable.}

\section{METHOD}

This is quantitative's research with explanatory approach. In this study, there is a hypothesis to examine for validity. The hypothesis shows the correlations between two variables, to examine a variable is correlated or not with other variables, or whether the variables are influenced by other variables [41]. The samples are permanent employees of PDAM in Malang City, as many as 75 employees. Data are collected by using questionnaire. The collected data will be analyzed by using the technique of path analysis. The analysis is used to explain whether there is a direct or indirect effect among the tested variables [42].

\section{RESULTS AND DISCUSSION}

Indirect Path Analysis Model depicted in Figure 1. $R$ square's result as follow in Table 1 .

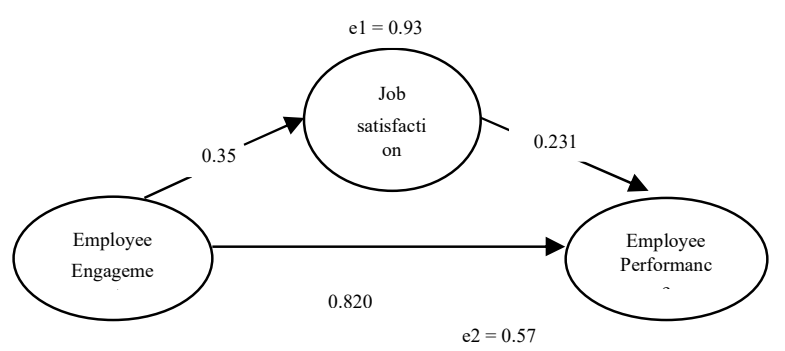

Figure 1 Indirect Path Analysis Model 


\subsection{Hypothesis Test}

The basic assumption of decision making for hypothesis testing is to use the t-statistic. The t-statistic value is greater than the t-table value, 1.960 , which shows a significant effect. The results of hypothesis testing are as follows in Table

Table 1 -square Value

\begin{tabular}{ll}
\hline & R-square \\
\hline Job satisfaction & 0.359 \\
Employee performance & 0.321 \\
\hline
\end{tabular}

Table 1 shows that the R-square value for job satisfaction variable is 0,359 and for employee performance variable is 0.321 . Goodness of Fit Model is measured using $Q$ Square $\left(\mathrm{Q}^{2}\right)$. The value of $\mathrm{Q}^{2}>0$ indicates predictive relevance model. The value of $\mathrm{Q}^{2}$ ranges from $0<\mathrm{Q}^{2}<1$ [41].

Each value of $\mathrm{R}^{2}$ is as follows:

$$
\mathrm{Q}^{2}=1-\left(1-\mathrm{R}_{1}{ }^{2}\right)\left(1-\mathrm{R}_{2}{ }^{2}\right)
$$

$$
\begin{aligned}
& \mathrm{Q}^{2}=1-(1-0.359)(1-0.321) \\
& \mathrm{Q}^{2}=0.565
\end{aligned}
$$

The value of $\mathrm{Q}^{2}$ is 0.565 or $56.5 \%$, the data contribution that the modal explains is $56.5 \%$. The remaining $43.5 \%$ explained by other variables is not in the model of this study.

Table 2 The Influence among Variables

\begin{tabular}{llllll}
\hline Variable & & t count & P Value & Koef. Line & Description \\
\hline $\begin{array}{llll}\text { Employee } \\
\text { Engagement }\end{array}$ & Job satisfaction & 3.284 & 0.002 & 0.359 & significant \\
$\begin{array}{l}\text { Employee } \\
\text { Engagement }\end{array}$ & Employee & 12.246 & 0.000 & 0.820 & significant \\
Job & $\begin{array}{l}\text { Performance } \\
\text { Employee }\end{array}$ & 2.893 & 0.005 & 0.321 & significant \\
\hline
\end{tabular}

Table 3 Results of Sobel Test

\begin{tabular}{cccccccc}
\hline Path & A & B & SEA & SEB & $t$ count & Sig & Description. \\
\hline TL-TI-SA & 0.359 & 0.321 & 0.115 & 0.074 & 2.534 & 0.011 & Sig
\end{tabular}

The above analysis concludes that the significant value of employee's engagement (X) is $0,000<0,05$, with $t$ count $12,246>t$ table 1,99346 , so employee engagement $(\mathrm{X})$ influence of employee performance (Y). Thus, the statement of $\mathrm{H} 1$ "employee engagement directly impacts on employee performance" is accepted.

It agrees with the research of [28], worker Engagement has a great influence on worker performance because when employees are very engaged with the entire organization and its components, the employee performance must increase. It is also supported by [29] that the organization with high level of employee engagement must be better than the competitors. Employee engagement gives companies competitive advantage through high productivity. [3] stated that employee engagement can lead to the company success through things related to satisfaction, employee commitment, employee loyalty, and employee productivity.
Job performance becomes one of the factors for high employee engagement.

The analysis above reveal that the significant value of job satisfaction $(\mathrm{Z})$ is $0.005<0.05$, and the obtained $\mathrm{t}$ count is $2.893>\mathrm{t}$ table 1.99346, its Job Satisfaction (Z) influence of Employee Performance (Y). Therefore, H2 is accepted.

Merry and Syarief which shows that job satisfaction have a positive effect with performance [13]. The more satisfied the employees are, the better the work performance and result will be, or the other way around. Aftab and Idrees that notes the relationship of satisfaction to performance is positive [43]. The satisfied workers are always productive. The results of the research go in line with the argument of [44], that managers must focus on employee job satisfaction, if they want to improve their business.

The significant value of employee engagement, (X) $0.002<0.05$ and $t$ count $3,284>t$ table 1,99346 , means that 
there is a significant influence (the constant value is 0.573 ) of employee engagement (X) on job satisfaction (Z). Therefore, H3 statement that employee engagement directly effect on Job Satisfaction is received. This research supported by [36] that satisfaction is a determinant of employee involvement. It also supports the research of [6] and [36] that satisfaction on job has an affirmative action on worker engagement. Affirmative effect is a positive word which strengthens one's confidence on the potential actions to realize. Employee engagement is realized by the behavior of the employees who often feel good moods, such as a blissfulness, excitement, and spiritness. The emotions provide support and transfer their engagement to others [37].

Testing the mediation hypothesis can be done through the Sobel Test with the Free Statistical Calculation software for Sobel Test version 4.0. To test the significance of the indirect effect, it is necessary to test the $t$ value. The $t$ value is compared with the $t$ table value. If the $t$ value $>t$ table, there is a mediating effect [45]. The result of the Sobel test is $2,534 \geq 1,960$. Therefore, job satisfaction as mediation variable.

Scahufeli and Bakker [7] define that employee involvement is a dedication, enthusiasm, and the full attention of the employees from positive thinking, satisfaction, and other things associated with their job. Employee engagement effects employee performance with employee satisfaction as one of the components. Markos and Sridevi [6], Oxy and Heru [40] also state that the concept of employee engagement is related to worker commitment and satisfaction on job. According to [39], employees who find job satisfaction will work better. It is also supported by the research of Ghafoor et al. [38] that once the employees feel as parts of this organization, personal identity with the organizational increases. Identities and relationship with the organization develop employee performance. These statements support the direct influence of employee satisfaction and sense of belonging on the quality of the relationship between employees and the organization.

\section{CONCLUSION}

Employee Engagement can improve employee performance because an organization with high level of employee engagement is upper hand than the competitors. The engaged employees provide a competitive advantage through the increase of productivity. Job satisfaction can improve employee performance. The more satisfied the employees are, the better the work performance and results will be. The satisfied workers are always productive. Employee engagement can increase employee job satisfaction. Employee engagement is realized by the behavior of the employees with positive emotions, such as blissfulness and excitement. Employees who are satisfied with their work, will work better.
Some of the conclusions from the analysis suggest that PDAM in Malang City is expected to keep maintaining and increasing the employee engagement and job satisfaction. Therefore, the employee engagement and job satisfaction can increase employee performance. Further researches are encouraged to develop the results of this study through additional variables, so the research models develop more.

\section{REFERENCES}

[1] A. M. Saks, "Antecedents and Consequences of Employee Engagement", Journal of Managerial Psychology, 21(7) (2006) 600-619

[2] D. Swati and S. Archana. "Role of organizational image in employee engagement and performance", Benchmarking: An International Journal, 26 (3) (2018) 971-998

[3] A. Siddhanta \& D. Roy, "Employee Engagement, Engaging the 21st Century Workforce". Asian Journal Management Research, (2010)

[4] www.pdamkotamalang,com diakses 20 februari 2020, http://www.pdamkotamalang.com/user/news_home

[5] A. W. Handoyo \& R. Setiawan, "Pengaruh Employee Engagement Terhadap Kinerja Karyawan". AGORA, 5(1) (2017).

[6] S. Markos, M. Sridevi, Sandhya. "Employee Engagement: The Key to Improving Performance". International Journal of Business and Management. 5(12) (2010).

[7] W.B. Scahufeli, \& A. B. Bakker, A. B. "Job Demands, Job Resources, And Their Relationship With Burnout Engagement: A Multi-Sample Study". Journal of Organizational Behavior, 25 (2004), 293315

[8] D. S. Lianasari, W. Paulus, "Pengaruh Stress Kerja, Employee Engagement, dan Kedisiplinan terhadap Kinerja dengan Kepuasan Kerja Sebagai Variabel Interverning Pada Karyawan CV. Karya Manunggal Semarang". Neo-Bis. 11 (2) (2017) 172-197.

[9] Y. Muliawan, Perizade, B., Cahyadi, A. (2017). Pengaruh Keterikatan Karyawan (Employee Engagement) Terhadap Kinerja Karyawan di PT. Badja Baru Palembang. Jurnal Ilmiah Manajemen Bisnis dan Terapan, 15 (2), 69-79.

[10] C. Jelagat \& C. Josphat, "An Empirical Analysis of Employee Engagement on Employee Performance in Technical Institutions in Kenya". International Journal of Advances in Management and Economics. 7 (2018).

[11] J. Anitha, "Determinants of Employee Engagement and Their Impact on Employee Performance". International Journal of Productivity and Performance Management. 63(3) (2014) 308-323. 
[12] M.A.Z. Dajani, "The Impact of Employee Engagement on Job Performance and Organisational Commitment in the Egyptian Banking Sector". Journal of Business and Management Sciences. 3(5), (2015) 138-147.

[13] L. Z. Merry \& F. Syarief. "The Effect of Empowerment, Employee Engagement and Organizational Comitment Towards Performance of Govermental-Employees of Financial-Management". IJHCM (International Journal of Human Capital Management). 1(01) (2017) 152-163.

[14] P.J. Vasani \& V.V. Pillai, "To Study on Employee Engagement and Their Impact on Employee Performance". (IJAR) International Journal of Applied Research. 5(4) (2019) 490-493.

[15] N. Widyastuti \& E. Rahardja, "Analisis Pengaruh Stres Kerja, Kompensasi, dan Employee Engagement terhadap Kinerja Pegawai (Studi pada Pegawai PDAM Tirta Moedal Kota Semarang)". Diponegoro Journal of Management, 7(1) (2018) 1-11.

[16] C. Chandra \& M. Remiasa, Pengaruh Employee Engagement Terhadap Kinerja Karyawan PT Intiland Grande. Agora, 6.(1) (2018).

[17] D. S. Siswono, "Pengaruh Employee Engagement Terhadap Kinerja Karyawan di Rodex Travel Surabaya". Agora. 4(2) (2016) 458-466.

[18] K. Sopyan \& E. Ahman. "Pengaruh Budaya Organisasi, Kepuasan Kerja, dan Keterikatan Karyawan (Employee Engagement) terhadap Kinerja Karyawan di Dinas Perhubungan, Komunikasi dan Informatika (Dishubkominfo) Kabupaten Sukabumi". Jurnal Ilmu Manajemen \& Bisnis. 6 (1) (2015).

[19] R. A. Kusumawati, "Pengaruh Employee Engagement terhadap Kinerja Karyawan Program Diploma III di Fakultas Ekonomi Universitas Islam Indonesia". Jurnal Maksipreneur. VI(2), (2017). 117.

[20] S.A. Joushan, M. Syamsun, L. Kartika, "Pengaruh Budaya Organisasi dan Employee Engagement terhadap Kinerja Karyawan pada PT PLN (Persero) Area Bekasi". Jurnal Aplikasi Manajemen, 13(4), (2015) 697-703.

[21] A. Azizah \& A. Gustomo, "The Influence of Employee Engagement to Employee Performance at PT Telkom Bandung". Journal of Business and Management, 4(7) (2015).

[22] A. Vorina, S. Miro, V. Maria. "An Analysis of the Relationship Between Job Satisfaction and Employee Engagement". Economic Themes. 55(2) (2017), 243262.

[23] P. Thakur. "A Research Paper on the Effect of Employee Engagement on Job Satisfaction in IT Sector". Journal of Business Management \& Social Science Research (JBM \& SSR). 3(5) (2014).
[24] B. S. Priyono, L. Lilik. "The Role of Work Satisfaction as Interverning Variable in the Influence of Employee Engagement and Competency to Performance", in The SixthInternational Conference on Entrepreneurship and Business Management (ICEBM 2017) Hanoi,Vietnam-November (2017) pp.16-17.

[25] Shamailan, S. B. Abdulwahab, "The relationship between job satisfaction, job performance and employee engagement: An explorative study". Business Management and Economics. 4(1) (2016) $1-8$.

[26] R. Veithzal, Manajemen Sumber Daya Manusia untuk Perusahaan, Jakarta: PT. Raja Grafindo Persada, 2008

[27] R. Harsuko, Mendongkrak Motivasi dan Kinerja: Pendekatan Pemberdayaan SDM. Malang: UB Press, 2011

[28] A.Y. Nurbaity \& H. Sulistyo,"Pendekatan Engagement dalam Membangun Kinerja Pegawai". EKOBIS, 14(2) (2013) 44-58.

[29] B. K. Sundaray, "Employee Engagement: A Driver of Organizational Effectiveness". European Journal of Business and Management, 3(8) (2011).

[30] C. Aprianto, S. Yoyok, "Pengaruh Motivasi Terhadap Kepuasan Kerja Serta Dampaknya Terhadap Kinerja Karyawan di PT. X". Jurnal Ilmu Manajemen, 4 (2) (2016).

[31] A. Sani, B.E. Soetjipto, V. Maharani. "The Effect Of Spiritual Leadership On workplace Spirituality, Job Satisfaction Andihsan Behaviour (A Study On Nurses Of Aisyiahislamic Hospital In Malang, Indonesia)". IJABER, 14(11) (2016) 7675-7688.

[32] S.P. Robbins and T.A. Judge, "Organizational Behavior (Perilaku Organisasi)". Jakarta: Salemba Empat, 2009

[33] A.P. Mangkunegara, Manajemen Sumber Daya Manusia Perusahaan. Bandung: Rosdakarya, 2011

[34] S. Siswanto, A. Supriyanto, U. "Ni'mah, N. Asnawi, \& I. Wekke, Does a workload influence the performance of bank employees?" Management Science Letters, 9(5) (2019) 639-650.

[35] A.S. Supriyanto, V.M. Ekowati, U. Maghfiroh, "Do organizational citizenship behavior and work satisfaction mediate the relationship between spiritual leadership and employee performance", Management Science Letters, 10 (2020) 1107-1114.

[36] A.E.L. Siswanto, "The Determinant of Employee Engagement". Iqtishadia: Jurnal Ekonomi dan Perbankan Syariah, 6 (2) (2019) 119-130.

[37] M. Bedarkar, D. Pandita, "A study on the drivers of employee engagement impacting employee performance". Procedia -Social and Behavioral Sciences 133 (2014) $106-115$. 
[38] A. Ghafoor, T.M. Qureshi, A.M. Khan, S.T. Hijazi, "Transformational Leadership, Employee Engagement and Performance: Mediating Effect of Psychological Ownership". African Journal of Business Management, 5 (17), (2011) 7391-7403.

[39] T. H. Handoko, Manajemen Personalia dan Sumber Daya Manusia. Edisi II, Cetakan Keempat Belas. Yogyakarta: BPEE, 2000.

[40] R.S. Oxy \& S. Heru, "Pengaruh Kepuasan Kerja terhadap Kinerja Karyawan dengan Organizational Citizenship Behavior Sebagai Variabel Interverning". Jurnal Administrasi Bisnis (JAB). 64 (1) (2018) 2835.

[41] A.S. Supriyanto dan V. Maharani, Metode Penelitian Sumber Daya Manusia Teori, Kuisioner, dan Analisis Data. Malang: UIN-Malang Press, 2013.
[42] A. Kuncoro \& E. Riduwan, Cara Menggunakan dan Memakai Analisis Jalur. Bandung: Alfabeta, 2008

[43] H. Aftab, and W. Idrees. "A Study of Job Satisfaction and IT's Impact on the Performance In the Banking Industry of Pakistan". International Journal of Business and Social Science. 3(19) (2012).

[44] A. Susanti \& R. Miradipta, R. "Analysis of the Effect of Attitude Towards Works, Organizational, Commitment, and Job Satisfaction, on Employees Job Performance". European Journal of Business and Social Sciences. 1(10) (2013) 15-24.

[45] I. Ghozali, Aplikasi Analisis Multivariate Dengan Program IBM SPSS 21. Semarang: Universitas Diponegoro, 2013. 